\title{
Water Quality Indices: Current and Future Trends in Evaluating Contamination of Groundwater Resources
}

\author{
Dimitrios E. Alexakis
}

Citation: Alexakis, D.E. Water Quality Indices: Current and Future Trends in Evaluating Contamination of Groundwater Resources. Water 2021, 13, 401. https://doi.org/ 10.3390/w13040401

Academic Editor: Adriano A. Bordalo Received: 20 January 2021

Accepted: 3 February 2021

Published: 4 February 202

Publisher's Note: MDPI stays neutral with regard to jurisdictional claims in published maps and institutional affiliations.

Copyright: (C) 2021 by the author Licensee MDPI, Basel, Switzerland. This article is an open access article distributed under the terms and conditions of the Creative Commons Attribution (CC BY) license (https:// creativecommons.org/licenses/by/ $4.0 /$ )
Laboratory of Geoenvironmental Science and Environmental Quality Assurance, Department of Civil Engineering, School of Engineering, University of West Attica, 250 Thivon \& P. Ralli Str., 12244 Athens, Greece; d.alexakis@uniwa.gr; Tel.: +30-210-5381256

Groundwater and surface water contamination is related to the presence of chemical substances, which strongly influence the water suitability for human consumption as well as for industrial and agricultural uses. The evaluation of water contamination and the investigation of any links between water quality and human health are critical elements of the legislation and guidelines developed by various researchers and agencies.

Although many scientists and engineers have performed meticulous research on a large number of issues related to water contamination, it is clear that there is a lack of mature and scientifically sound procedures in a variety of topics. One of these topics is the documentation of a globally accepted single value or score that expresses the water quality of an aquifer in terms of a water quality index. Water quality indices (WQIs) aim to be practical and compelling tools for the water quality management and sustainable development of water resources.

The scientific field of water quality is wide-ranging and far-reaching. A gradual decline in water quality is among the main results of agricultural, industrial, and domestic growth and other changes in land use. Evidently, well-structured planning of water resources is the key to protect water quality and evaluate and manage the contamination of groundwater and surface water.

The published papers in the Special Issue focus on research topics including water quality, water contamination, and water quality indices. Various factors controlling water quality are presented in this Special Issue. In fact, the collected papers report novel investigation and experimental results.

Alexakis [1] proposed a meta-evaluation approach of two widely used WQIs through the classification proposed by the Water Framework Directive (WFD; 2000/60/EC) and the Groundwater Directive (GWD; 2006/118/EC). The WQIs of the Canadian Council of Ministers of Environment (CCME) and the National Sanitation Foundation (NSF) were selected for evaluation. It was shown that applying different WQI methodologies produces appreciable differences in the estimated WQI values and qualitative classification. The comparison of CCME-WQI and NSF-WQI values revealed that the CCME-WQI is a rather strict index since it estimates statistically significant lower values than the NSF-WQI. At a significance level $\mathrm{a}=0.05$ for the calculated WQI values of the area studied, the student's $t$ statistical test revealed that CCME-WQI values are significantly lower compared to NSF-WQI values.

The paper of Emmanouil et al. [2] investigated the presence of ingredients of personal care products (PCPs) in the effluents of wastewater treatment plants (WWTPs) in Greece. The examined ingredients, which are degraded in WWTPs at various removal rates, included triclosan, parabens, synthetic musks (parfums), and UV filters. An apparent decrease in the occurrence of parabens and triclosan in the effluents of WWTPs was recorded. According to Emmanouil et al. [2], the multitude and the variability of ingredients found in PCPs pose a threat to wastewater treatment and reclamation, and the monitoring of PCPs in WWTPs should be updated. 
The study by Giannakis et al. [3] evaluated the effects of municipal sludge leachates on water quality. The main physicochemical parameters were determined in the leachates of sludge samples by applying two leaching methods (EN 12457-2 and NEN 7341). The findings revealed that almost all leachates showed acute toxicity for Daphnia magna, while only some EN 12457-2 or NEN 7341 leachates showed acute toxicity on Vibrio fischeri. The toxicity of the examined leachates toward Daphnia magna and Vibrio fischeri was recorded to be insignificant when the quite-toxic sludge sample was mixed with sandy or clay soil. A reduction was recorded for the $\mathrm{pH}$ values of leachates, while an increase was observed for nitrates and nitrites.

The Feng et al. [4] paper evaluated the hydrochemical characteristics and hydrogeochemical processes of shallow groundwater in the Jinta Basin (China) and assessed the quality of groundwater for drinking and irrigation purposes. Sodium adsorption ratio (SAR), sodium percentage (Na \%), Kelly's Ratio (KR), the Permeability Index (PI), and a water quality index (WQI) were applied to determine the suitability of groundwater for various uses.

Golfinopoulos et al. [5] presents an overview of the status of arsenic (As) contamination and its sources in two European countries, Greece and Cyprus. The presence of As in surface water, stream and marine waters, groundwater, bottled water, sediment, soil, mines, and seafood; its environmental origin; and its impacts on human health were evaluated. The classes of the Geoaccumulation Index for As in soil and sediments ranges from practically uncontaminated to extremely contaminated and from practically uncontaminated to heavily contaminated in Greece and Cyprus, respectively. In many studied cases, the As contamination reaches high levels and the impacts may be crucial for human health and ecosystems. The results reported by Golfinopoulos et al. [5] may be useful for scientists and stakeholders monitoring Greece and Cyprus and for applying measures for the protection of humans and terrestrial ecological receptors (plants, avian, mammals).

Each of the published papers in this Special Issue provides contributions on the research in water quality and the evaluation of water contamination and suggests possible research topics to be implemented in the future. This Special Issue also provides new knowledge that directly helps those currently involved in water quality management. In addition to this thematic issue, there are several MDPI journals (Water, Land, Hydrology) that publish a large number of papers dealing with water-quality-related issues.

Funding: This research received no external funding.

Acknowledgments: Dimitrios E. Alexakis, Guest Editor, is grateful for the considerable support and assistance that in-house editors from Water Editorial Office, have provided over the past 12 months. The Guest Editor also greatly appreciates the reviewers who have dedicated their expertise and valuable time to the rigorous editorial process of the Special Issue.

Conflicts of Interest: The author declares no conflict of interest.

\section{References}

1. Alexakis, D. Meta-Evaluation of water quality indices. Application into groundwater resources. Water 2020, 12, 1890. [CrossRef]

2. Emmanouil, C.; Bekyrou, M.; Psomopoulos, C.; Kungolos, A. An insight into ingredients of toxicological interest in personal care products and a small-scale sampling survey of the Greek market: Delineating a potential contamination source for water resources. Water 2019, 11, 2501. [CrossRef]

3. Giannakis, I.; Emmanouil, C.; Kungolos, A. Evaluation of effects of municipal sludge leachates on water quality. Water 2020, 12, 2046. [CrossRef]

4. $\quad$ Feng, J.; Sun, H.; He, M.; Gao, Z.; Liu, J.; Wu, X.; An, Y. Quality assessments of shallow groundwaters for drinking and irrigation purposes: Insights from a case study (Jinta Basin, Heihe drainage area, Northwest China). Water 2020, 12, 2704. [CrossRef]

5. Golfinopoulos, S.K.; Varnavas, S.P.; Alexakis, D.E. The status of arsenic pollution in the greek and cyprus environment: An overview. Water 2021, 13, 224. [CrossRef] 